Louisiana State University

LSU Digital Commons

Faculty Publications

Department of Biological Sciences

$1-1-2006$

\title{
FGF2 binding, signaling, and angiogenesis are modulated by heparanase in metastatic melanoma cells
}

\author{
Jane Reiland \\ Louisiana State University \\ Doty Kempf \\ Louisiana State University \\ Madhuchhanda Roy \\ Louisiana State University \\ Yvonne Denkins \\ Louisiana State University \\ Dario Marchetti \\ Louisiana State University
}

Follow this and additional works at: https://digitalcommons.Isu.edu/biosci_pubs

\section{Recommended Citation}

Reiland, J., Kempf, D., Roy, M., Denkins, Y., \& Marchetti, D. (2006). FGF2 binding, signaling, and angiogenesis are modulated by heparanase in metastatic melanoma cells. Neoplasia, 8 (7), 596-606.

https://doi.org/10.1593/neo.06244

This Article is brought to you for free and open access by the Department of Biological Sciences at LSU Digital Commons. It has been accepted for inclusion in Faculty Publications by an authorized administrator of LSU Digital Commons. For more information, please contact ir@lsu.edu. 


\title{
FGF2 Binding, Signaling, and Angiogenesis Are Modulated by Heparanase in Metastatic Melanoma Cells ${ }^{1}$
}

\author{
Jane Reiland, Doty Kempf, Madhuchhanda Roy, Yvonne Denkins, and Dario Marchetti
}

Department of Comparative Biomedical Sciences-SVM, Louisiana State University-Baton Rouge, Baton Rouge, LA 70803, USA

\begin{abstract} Heparanase (HPSE) and fibroblast growth factor-2 (FGF2) are critical regulators of melanoma angiogenesis and metastasis. Elevated HPSE expression contributes to melanoma progression; however, further augmentation of HPSE presence can inhibit tumorigenicity. HPSE enzymatically cleaves heparan sulfate glycosaminoglycan chains (HS) from proteoglycans. HS act as both low-affinity FGF2 receptors and coreceptors in the formation of high-affinity FGF2 receptors. We have investigated HPSE's ability to modulate FGF2 activity through HS remodeling. Extensive HPSE degradation of human metastatic melanoma cells (70W) inhibited FGF2 binding. Unexpectedly, treatment of $70 \mathrm{~W}$ cells with low HPSE concentrations enhanced FGF2 binding. In addition, HPSE-unexposed cells did not phosphorylate extracellular signal-related kinase (ERK) or focal adhesion kinase (FAK) in response to FGF2. Conversely, in cells treated with HPSE, FGF2 stimulated ERK and FAK phosphorylation. Secondly, the presence of soluble HPSE-degraded HS enhanced FGF2 binding and ERK phosphorylation at low HS concentrations. Higher concentrations of soluble HS inhibited FGF2 binding, but FGF2 signaling through ERK remained enhanced. Soluble HS were unable to support FGF2-stimulated FAK phosphorylation irrespective of HPSE treatment. Finally, cell exposure to HPSE or to HPSE-degraded HS modulated FGF2induced angiogenesis in melanoma. In conclusion, these effects suggest relevant mechanisms for the HPSE modulation of melanoma growth factor responsiveness and tumorigenicity.

Neoplasia (2006) 8, 596-606
\end{abstract}

Keywords: Heparanase, heparan sulfate, FGF2 binding, angiogenesis, malignant melanoma.

\section{Introduction}

How cancer cells respond differentially to growth factors plays a major role in cancer progression. One family of molecules, heparan sulfate proteoglycans (HSPG) ${ }^{1}$, is present both on the cell surface and in the surrounding extracellular matrix $(E C M)$ and plays a major role in cellular behavior, leading to tumor growth and metastasis [1]. Much of HSPG biologic activity is mediated by their heparan sulfate glycosaminoglycan chains (HS) through the binding of a wide variety of growth factors, growth factor receptors, and adhesion molecules [2]. In addition, quantitative and qualitative changes occur in HS expressed by metastatic versus normal cells [2]. These include variations in chain sequence, sulfation, and length $[2,3]$, leading to alterations in the ability of HS to modulate biologic activity [4].

HS sequence and length are regulators of fibroblast growth factor-2 (FGF2) activity, an important mediator of melanoma angiogenesis and progression [5]. HS bind to both FGF2 and FGF receptors (FGFR) [6]. Cell surface HSPG are low-affinity receptors for FGF2 through their HS. HSPG also form a ternary complex with FGF2 and their tyrosine kinase-containing FGFR, resulting in the formation of high-affinity binding sites $[7,8]$. Finally, soluble HS or the highly sulfated form of HS, heparin, can mediate the binding of FGF2 to FGFR, bypassing the need for cell surface HSPG [6].

FGF2 binding phosphorylates both extracellular signalrelated kinase (ERK) and focal adhesion kinase (FAK), although not necessarily through the same signaling pathway $[9,10]$. Signal transduction pathways that include ERK are important regulators of cell growth and invasion and are altered during melanoma progression to metastatic phenotype [11,12]. ERK is also phosphorylated in response to a wide variety of extracellular signals, including adhesion molecules and growth factors, whereas FAK is activated during integrin binding and mediates signal transduction for biologic functions such as adhesion, migration, and survival [13]. For example, pathways that stimulate ERK phosphorylation in melanoma cells may then affect the production of angiogenic factors. ERK and FAK can also participate in shared signaling pathways (i.e., when integrin-induced FAK phosphorylation stimulates ERK signaling) [14]. However,

\footnotetext{
Abbreviations: DME/F-12, Dulbecco's modified Eagle's F-12 medium; ECM, extracellular matrix; ERK, extracellular signal-regulated kinase; FAK, focal adhesion kinase; FGF2, fibroblast growth factor-2; FGFR, FGF receptors; Hep I, heparitinase I; Hep III, heparitinase III; HPSE, heparanase; HS, heparan sulfate glycosaminoglycan chains; HSPG, heparan sulfate proteoglycans

Address all correspondence to: Dr. Dario Marchetti, Department of Comparative Biomedical Sciences-SVM, Louisiana State University-Baton Rouge, Room 2522, Skip Bertman Drive, Baton Rouge, LA 70803. E-mail: dmarchett@vetmed.Isu.edu

${ }^{1}$ This work was supported by a grant from the Governor's Biotechnology Initiative of the State of Louisiana and by grants from the National Institutes of Health (5R0-1CA86832 and 1R21 CA 103955, to D.M.), Phillip Morris USA, and Phillip Morris International (to D.M). Received 20 March 2006; Revised 15 May 2006; Accepted 17 May 2006.
}

Copyright $\odot 2006$ Neoplasia Press, Inc. All rights reserved 1522-8002/06/\$25.00 DOI 10.1593/neo.06244 
depending on the cellular system, ERK may be upstream of FAK [15], FAK may act as a potentiator of ERK signaling [16], or ERK may be independent of FAK activation [17,18].

HS remodeling by bacterial heparitinases modulates FGF2 binding, signaling, and subsequent activity. Depending on cell type and method of removal, degradation of cell surface $\mathrm{HS}$ can prevent the formation of high-affinity ternary complexes [19]. Free HS released by heparitinase can then act as either promoters or inhibitors of growth factor actions [20]. Conversely, FGF2 binding and activity can be affected to differing extents, particularly as ligand binding to a small number of receptors can stimulate a biologic response [21]. Heparanase (HPSE) has differential effects on growth factor activity, depending on the HS sequence it cleaves and the $\mathrm{HS}$ tissue origin. For example, soluble HS cleaved by bacterial heparitinase I (Hep I) promote FGF2 activity, whereas heparitinase III (Hep III)-cleaved HS do not [22].

Mammalian HPSE is an endoglycosidase (endo- $\beta$-D-glucuronidase), which degrades $\mathrm{HS}$ in a sequence-dependent manner [23]. It produces HS fragments larger than those produced by bacterial Hep I or Hep III enzymes; thus far, it has not been as well studied for its effects on growth factor activity. There are indications that HPSE activity is important in remodeling $\mathrm{HS}$ and in subsequent modification of growth factor activity (e.g., HPSE treatment of soluble syndecan-1, an important HSPG implicated in tumor biology, converts syndecan-1 from an inhibitor of FGF2 activity to a promoter of FGF2-stimulated mitogenesis) [24]. Early studies found that HPSE can increase the cellular availability of FGF2 by releasing sequestered FGF2 from the ECM into a bioactive form [2].

Of relevance, HPSE protein expression is upregulated in a wide variety of cancers [23], including malignant melanoma [25]. Overexpression of HPSE in transfected lymphoma [26] or melanoma cells [27] has been shown to augment tumor metastasis and angiogenesis. Likewise, inhibition of HPSE expression with antisense or siRNA techniques resulted in a significant decrease in melanoma metastatic phenotype $[27,28]$. However, it has been shown in a glioma model system that moderate levels of HPSE promoted tumor growth and invasion, whereas higher levels did not, indicating concentration dependence for its activity [29].

The present study focuses on HPSE's ability to both enhance and inhibit FGF2 binding and activity in an HPSE concentration-dependent manner. We studied HPSEgenerated remodeling of both cell surface and soluble HS by determining how: 1) HPSE cleavage of cell surface HSPG modifies FGF2 binding and signaling; 2) HS produced by HPSE degradation modulate FGF2 binding and signal transduction; and 3) FGF2-induced angiogenesis is enhanced by HPSE and HPSE-generated HS at the same concentrations that augment FGF2 binding and signaling.

\section{Materials and Methods}

\section{Tissue Culture and Enzymatic Treatments}

Human 70W melanoma cells, which possess high metastatic abilities compared to MeWo parental counterparts [30], were maintained as subconfluent monolayer cultures in Dulbecco's modified Eagle's F-12 medium (DME/F-12) supplemented with $10 \%$ (vol/vol) fetal bovine serum, as previously described [30]. Cells were washed thrice in DME/F-12 containing $0.1 \%$ bovine serum albumin (BSA) and penicillin/ streptomycin, then incubated with indicated concentrations $(0-5 \mu \mathrm{g} / \mathrm{ml})$ of recombinant HPSE in $10 \mathrm{mM}$ HEPES-buffered DME/F-12 (pH 6.8) containing 0.1\% BSA and penicillin/ streptomycin, or with Hep III in $10 \mathrm{mM}$ HEPES-buffered DME/F-12 (pH 7.4) containing 0.1\% BSA and penicillin/ streptomycin for 18 hours at $37^{\circ} \mathrm{C}$. For Hep III-treated cells, an additional aliquot of enzyme was added on the last hour of incubation to counter possible enzyme inactivation. The above conditions were chosen for different enzyme optimum values for $\mathrm{pH}$ and time while maintaining experimental conditions as close as possible. Cells were washed thrice with $\mathrm{DME} / \mathrm{F}-12$ containing $0.1 \% \mathrm{BSA}$ and penicillin/streptomycin before initiating the experiments.

\section{HPSE Isolation and Activity}

Recombinant human HPSE was purified as previously described [30,31]. Briefly, Sf9 insect cells, transfected with baculovirus transfer vectors containing HPSE subunits, were grown in SF900II serum-free medium (Gibco BRL, Grand Island, NY) for high-titer stocks. Tni cells cultured in suspension using ExCell405 serum-free medium (JRH Bioscience, Lenexa, KS) were infected with high-titer stock for 48 hours, and cells were subsequently removed by centrifugation. The supernatant was then tested for HPSE activity, filtered through a 0.45- $\mu \mathrm{m}$ filter, and loaded on a HiTrap heparin column (Amersham Biosciences, Piscataway, NJ). The column was subsequently washed in Tris-buffered saline (TBS) then eluted using a $100-\mathrm{ml}$ gradient of 0.15 to $1.0 \mathrm{M}$ $\mathrm{NaCl}$ in $25 \mathrm{mM}$ Tris- $\mathrm{HCl}(\mathrm{pH}$ 7.5). Collected fractions (1 ml) were screened for HPSE activity (Heparan Degrading Enzyme Assay Kit; Takara Mirus, Madison, WI) [30]. HPSE eluted at $0.67 \mathrm{M} \mathrm{NaCl}$, as expected [31].

\section{Immunofluorescent Staining}

$70 \mathrm{~W}$ cells were plated at $10 \%$ density in Lab-Tekll chamberslides (Nalge Nunc International, Rochester, NY) in DME/ $\mathrm{F}-12-10 \%$ (vol/vol) fetal bovine serum and allowed to attach and grow for 24 hours. Cells were treated with HPSE or Hep III as described above, and cell surface HS were detected using an anti-heparan sulfate monoclonal antibody (mAb) 10E4 (1:50 dilution; Seikagaku America, Falmouth, MA) followed by incubation with AlexaFluor 488 goat-antimouse IgM (1:400 dilution; Molecular Probes, Eugene, OR). Digital images were produced using an Axioplan fluorescent microscope (Carl Zeiss Microimaging, Thornwood, NY) with Microfire digital camera (Optronics, Goleta, CA) and Pictureframe imaging program (Optronics) using identical conditions for all photographs.

\section{Cellular HS Labeling and Degradation}

$70 \mathrm{~W}$ cells were plated in 24-well tissue culture plates for 24 hours to allow cell attachment. Cells were labeled with $20 \mu \mathrm{Ci} / \mathrm{ml}\left[{ }^{35} \mathrm{~S}\right]$ sulfate (Amersham Biosciences) for 24 hours, 
washed with DME/F-12 containing $0.1 \%$ BSA and penicillin/ streptomycin, and treated with HPSE or Hep III, as described above. The medium was sampled at 0-hour time point to assure adequate washing. Conditioned medium was collected at 18 hours, added to Ultimate Gold (PerkinEImer Life and Analytical Sciences, Boston, MA) scintillation cocktail, and counted in a liquid scintillation analyzer (PerkinElmer Life and Analytical Sciences). Cells were solubilized, and associated $\left[{ }^{35} \mathrm{~S}\right]$ sulfate was counted. Cell-associated and released counts were added for total $\left[{ }^{35} \mathrm{~S}\right]$ sulfate.

\section{HS Degradation and Analysis}

To degrade heparin or HS (bovine kidney HS; SigmaAldrich, St. Louis, MO), $250 \mathrm{ng}$ of $\mathrm{HS}$ was incubated for 16 hours at $37^{\circ} \mathrm{C}$ with either HPSE $(10 \mu \mathrm{g} / \mathrm{ml})$ in $20 \mathrm{mM}$ sodium acetate $(\mathrm{pH} 5.0)$, or Hep III $(0.1 \mathrm{mg} / \mathrm{ml})$ in $10 \mathrm{mM}$ Tris$\mathrm{HCl}\left(\mathrm{pH} 7.4\right.$ ), $150 \mathrm{mM} \mathrm{NaCl}$, and $4 \mathrm{mM} \mathrm{CaCl}_{2}$ (final volume, $70 \mu \mathrm{l})$. Hep III-mediated degradation could be achieved in two 30-minute incubations; however, to mimic conditions for HPSE, a longer incubation time was maintained. Following digestion, enzymes were inactivated for 10 minutes at $100^{\circ} \mathrm{C}$. Mock digestions were performed without enzymes as controls. Additional controls were performed using these enzymes without the presence of heparin or HS (data not shown).

HPSE-degraded HS used in binding and signaling experiments was analyzed by separating $\mathrm{HS}$ and heparin on a Criterion 4-20\% TBE gel (Bio-Rad Laboratories, Hercules, CA) for 20 minutes at $60 \mathrm{~mA}$. Bands were visualized with Alcian blue 8GX (Sigma-Aldrich), followed by silver staining (Pierce Endogen, Rockford, IL) [32]. Densitometric analyses were performed using a Versadoc imaging system (Bio-Rad Laboratories) to determine profiles' leading edge.

HPSE activity was determined by the degradation of a high-molecular-weight fraction of FITC-HS, which was prepared by employing the same HS used for binding and signal transduction experiments. FITC-HS was incubated for 0 to 24 hours with HPSE, as per above. After HPSE inactivation, the $\mathrm{pH}$ was adjusted using $0.5 \mathrm{M}$ Tris ( $\mathrm{pH} 8.0)$, and FITC-HS was analyzed using high-speed TSK gel permeation column chromatography [high-performance liquid chromatography (HPLC)], as previously described [30].

\section{FGF2 Binding Assays}

A widely accepted [ $\left.{ }^{125} \mathrm{I}\right] \mathrm{FGF} 2$ binding assay was used in our analyses [20,22]. Cells were plated in 24-well gelatincoated tissue culture plates for 24 to 48 hours to allow cell adhesion. Cells were treated with HPSE or Hep III, as described above. Cells were washed thrice with binding buffer [HEPES-buffered DME/F-12 (pH 7.4) containing 0.2\% BSA] at $4^{\circ} \mathrm{C}$, and cells were subsequently assayed for [ $\left.{ }^{125} \mathrm{I}\right] \mathrm{FGF} 2$ (Amersham Biosciences) binding, as previously reported $[20,33]$. Briefly, cells were incubated for 3 hours with 200 pM $\left[{ }^{125} \mathrm{I}\right] \mathrm{FGF} 2$ in binding buffer at $4^{\circ} \mathrm{C}$. They were then washed thrice with $20 \mathrm{mM}$ HEPES ( $\mathrm{pH} 7.4$ ) containing $150 \mathrm{mM} \mathrm{NaCl}$ and $0.2 \% \mathrm{BSA}$ at $4{ }^{\circ} \mathrm{C}$. Low-affinity $\mathrm{HSPG}$ binding sites were detected by two collected 1-ml washes of $20 \mathrm{mM}$ HEPES $(\mathrm{pH} 7.4)$ containing $2 \mathrm{M} \mathrm{NaCl}$ and $0.2 \% \mathrm{BSA}$ at $4^{\circ} \mathrm{C}$. Highaffinity FGFR complex binding sites were detected by two collected 1-ml washes of $20 \mathrm{mM}$ sodium acetate ( $\mathrm{pH} 4.0)$ containing $2 \mathrm{M} \mathrm{NaCl}$ and $0.2 \% \mathrm{BSA}$ at $4{ }^{\circ} \mathrm{C}$. Collected washes were counted in a Clinigamma counter (LKB Wallac, Gaithersburg, MD). For $\left[{ }^{125} \mathrm{I}\right] \mathrm{FGF} 2$ binding assays in the presence of soluble HS, $\left[{ }^{125} \mathrm{I}\right] \mathrm{FGF} 2$ and HS $(0-1000 \mathrm{ng} / \mathrm{ml})$ were added together, and assays were continued as described above. Control experiments were performed with unlabeled FGF2 to determine nonspecific binding. Results were reported as the relative binding of experimental condition compared to untreated or mock-treated controls. Significant differences in $\left[{ }^{125} \mathrm{I}\right] \mathrm{FGF} 2$ binding were determined by Student's $t$ test.

\section{Western Blot Analysis of ERK and FAK Phosphorylation}

For signal transduction studies, cells were plated in 12 -well tissue culture wells for 48 hours to allow cell adhesion. HPSE treatments of cell surface HS were performed as described above. Cells were exposed to $10 \mathrm{ng} / \mathrm{ml} \mathrm{FGF2} \mathrm{for}$ 10 minutes at $37^{\circ} \mathrm{C}$. Where indicated, FGF2 was added together with 0 to $1000 \mathrm{ng} / \mathrm{ml} \mathrm{HS}$. Following stimulation, the medium was aspirated from cells, and $100 \mu \mathrm{l}$ of lysis buffer [20 mM Tris- $\mathrm{HCl}(\mathrm{pH} 7.4)$ containing 1\% sodium dodecyl sulfate, $1 \mathrm{mM}$ phenylmethylsulphonyl fluoride, $0.1 \mathrm{mM}$ 4-(2aminoethyl)benzenesulfonyl fluoride, $0.1 \mathrm{mM}$ sodium molybdate, $1 \mathrm{mM}$ sodium orthovanadate, and $5 \mu \mathrm{g} / \mathrm{ml}$ aprotinin] was added at $4^{\circ} \mathrm{C}$. Lysed cells were scraped from the dish and put through three to six cycles of freezing in liquid nitrogen and heating up to $100^{\circ} \mathrm{C}$ for 5 minutes.

Samples for Western blot analysis were incubated at $100^{\circ} \mathrm{C}$ for 5 min with Laemmli sample buffer and separated on a 4-15\% Criterion gel (Tris- $\mathrm{HCl}$; Bio-Rad Laboratories). Proteins were transferred to polyvinylidene difluoride membrane (Pierce Endogen). Membranes were incubated in a blocking reagent [3\% (wt/vol) nonfat dry milk and 0.5\% (wt/ vol) BSA in TBS] for 2 hours, and then a buffer was added for an additional 30 minutes. Membranes were then incubated for 16 hours in blocking reagent with one of the following primary antibodies: anti-phosphorylated FAK (tyrosine 397) polyclonal antibody (Biosource International, Camarillo, CA), anti-FAK polyclonal antibody, anti-ERK mAb, or anti-phosphorylated ERK mAb (Cell Signaling Technology, Beverly, MA). Membranes were washed for 1 hour with six to eight changes of TBS containing $0.5 \%$ IGE-PAL (CA-630; SigmaAldrich) and incubated with horseradish peroxidaseanti-mouse or anti-rabbit IgG (1:10,000 dilution; Accurate Chemical and Scientific Co., Westbury, NY). Membranes were then washed and developed using the Supersignal west femto maximum sensitivity substrate (Pierce Endogen). Labeling was detected and quantified using a Versadoc imaging system (Bio-Rad Laboratories).

\section{Angiogenic Assays}

Where indicated, cells were pretreated with HPSE or mock-treated, as per above. 70W cells were then released with a brief trypsin treatment and added to $1 \mathrm{mg} / \mathrm{ml}$ soybean trypsin inhibitor in DME/F-12 containing $0.1 \% \mathrm{BSA}$, washed twice in DME/F-12, and resuspended at $1 \times 10^{7} \mathrm{cells} / \mathrm{ml}$ in $50 \%$ reduced growth factor Matrigel (Becton Dickinson, 
Labware, Bedford, MA) in DME/F-12 at $4^{\circ} \mathrm{C}$. HPSE, HS fragments, and FGF2 (10 ng/ml) were added accordingly. With the use of a 25 -gauge needle, cells $\left(2 \times 10^{6}\right)$ were injected to the left and right abdominal subcutaneous tissues of female nude mice (Harlan Teklan, Madison, WI). Mice were sacrificed on day 10, tumors were excised, fixed in $10 \%$ formalin, embedded in paraffin, and cut to $7-\mu \mathrm{m} \mathrm{sec}-$ tions, which were stained with hematoxylin and eosin (H\&E). Blood vessel density was assessed by examining three independent areas in each of three independent sections. Significant differences in angiogenesis were determined by Student's $t$ test and 90\% confidence intervals, using Microsoft Excel (Microsoft Corporation, Redmond, WA).

\section{Results}

\section{HPSE Action Remodels Cell Surface HS}

The extent of HS remodeling on $70 \mathrm{~W}$ by HPSE was assessed both by immunofluorescence and by the release of metabolically labeled HS into the culture medium. No detectable reduction in HS expression levels was seen by immunofluorescent labeling of $\mathrm{HS}$ after treating cells with $5 \mathrm{ng} / \mathrm{ml}$ HPSE versus no HPSE (Figure 1, $A$ and $B$ ). When cells were treated with higher HPSE concentrations (50$500 \mathrm{ng} / \mathrm{ml}$ ), a decrease in cell surface HS expression was observed (Figure 1, $C$ and $D$ ). HS expression also diminished when cells were exposed to increasing Hep III concentrations (Figure 1, $E$ and $H$ ). Comparable results were obtained when cells, whose HS were metabolically labeled with $\left[{ }^{35} \mathrm{~S}\right]$ sulfate, were treated with HPSE and then radiolabeled HS in the culture medium were monitored. Lower HPSE concentrations (50 $\mathrm{ng} / \mathrm{ml}$ and below) did not result in significant HS in the medium (Figure 1/). However, HPSE effectively released HS at higher concentrations (100$2500 \mathrm{ng} / \mathrm{ml}$ ). Hep III release of labeled HS was linear between 5 and $2500 \mathrm{ng} / \mathrm{ml} \mathrm{Hep} \mathrm{III} \mathrm{(Figure} \mathrm{1/).} \mathrm{Although} \mathrm{Hep} \mathrm{III} \mathrm{cleaves}$ HS into smaller fragments, the degradation was not as complete, possibly due to the reincorporation of released HS into the cell.

\section{HPSE Action Modulates FGF2 Binding}

The integrity of HS on HSPG influences the binding of heparin-binding growth factors. To determine whether HPSE remodeling of HS affected FGF2 binding, 70W human melanoma cells were degraded with HPSE (0-2500 ng/ml) and assayed for FGF2 binding to low-affinity (HS) and highaffinity (FGFR ternary complex) sites [20,22]. Inhibition of low-affinity sites was detected at $50 \mathrm{ng} / \mathrm{ml}$ HPSE (24\% inhibition; $P<.005)$ and maximal inhibition (59\% inhibition; $P<.005$ ) was observed using $2.5 \mu \mathrm{g} / \mathrm{ml} \mathrm{HPSE}$ (Figure $2 A$ ). At the highest HPSE concentration $(2.5 \mu \mathrm{g} / \mathrm{ml})$, high-affinity binding was inhibited by $48 \%(P<.005)$; thus, HPSE cleaved sufficient cell surface HS to inhibit high-affinity FGF2 binding (Figure 2A). Notably, HPSE concentrations that did not inhibit binding to low-affinity sites $(5 \mathrm{ng} / \mathrm{ml})$ enhanced FGF2 high-affinity binding by $157 \%(P<.01)$ compared to nonHPSE-treated cells (Figure $2 A$ ).
Either the extent of HS degradation by enzymatic degradation or differences in sequence cleavage could affect FGF2 binding. Therefore, $70 \mathrm{~W}$ cells were treated with Hep III, a bacterial exoglycosidase that extensively cleaves HS at sites
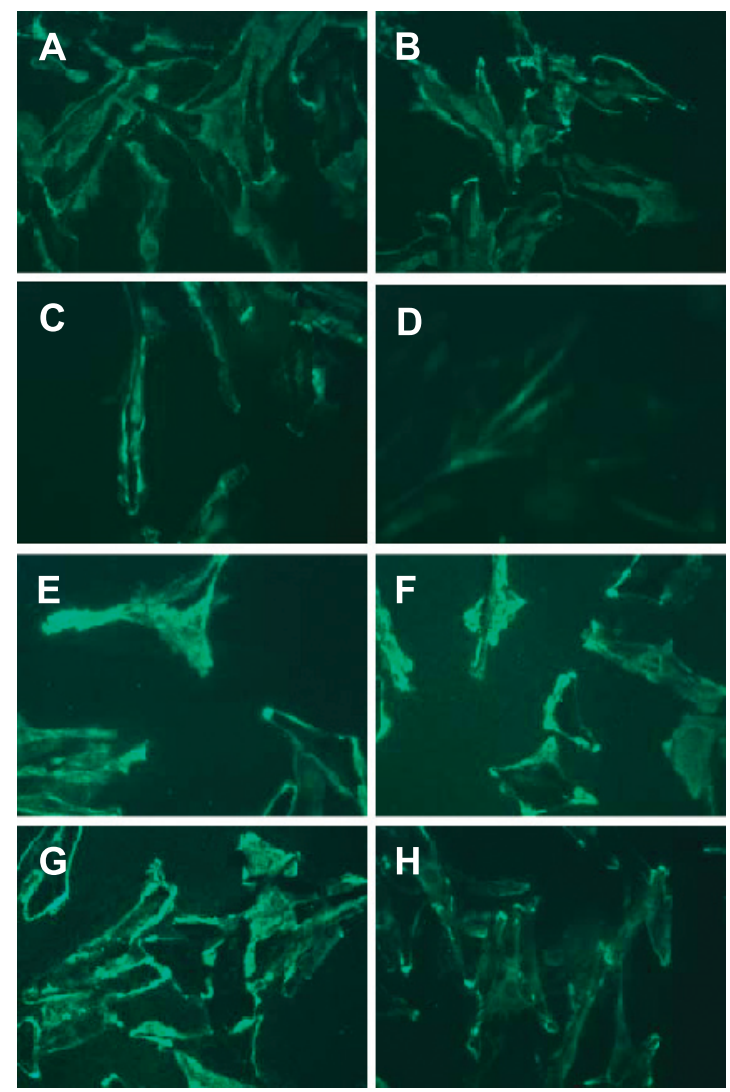

I

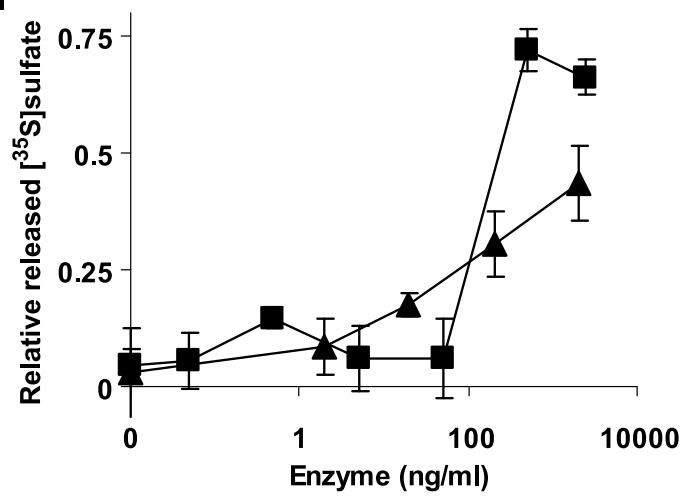

Figure 1. HPSE and Hep III degradation of cell surface HS $(A-H)$. Human $70 W$ melanoma cells, plated in chamber slides, were treated with $(A) 0 \mathrm{ng} / \mathrm{ml}$ HPSE, (B) $5 \mathrm{ng} / \mathrm{ml} \mathrm{HPSE,} \mathrm{(C)} 50 \mathrm{ng} / \mathrm{ml} \mathrm{HPSE,} \mathrm{(D)} 500 \mathrm{ng} / \mathrm{ml} \mathrm{HPSE}$, or (E) $0 \mathrm{ng} / \mathrm{ml} \mathrm{Hep} \mathrm{III,} \mathrm{(F)} 5 \mathrm{ng} / \mathrm{ml} \mathrm{Hep} \mathrm{III,} \mathrm{(G)} 50 \mathrm{ng} / \mathrm{ml} \mathrm{Hep} \mathrm{III,} \mathrm{and} \mathrm{(H)} 500 \mathrm{ng} / \mathrm{ml}$ Hep III. Cells were then fixed and immunostained for HS. All images were produced at identical conditions using an Axioplan fluorescent microscope with Microfire digital camera and Pictureframe imaging program (see Materials and Methods section for details). Images are representative of two independent experiments performed in duplicate. (I). Alternatively, 70W cells were metabolically labeled for 24 hours with $20 \mu \mathrm{Ci} / \mathrm{ml}\left[{ }^{35}\right.$ S]sulfate, washed to remove free sulfate, and incubated for 16 hours with indicated concentrations of HPSE ( $\mathbf{\square}$ ) or Hep III ( $\mathbf{\Delta}$ ). Conditioned medium and cell-associated $\left[{ }^{35} \mathrm{~S}\right]$ sulfate were counted in a liquid scintillation counter and reported as mean fraction of ${ }^{35}$ S]sulfate released into the medium compared to mean total ${ }^{35}$ S]sulfate (see Materials and Methods section for details) from triplicate determinations ( \pm standard deviations). 

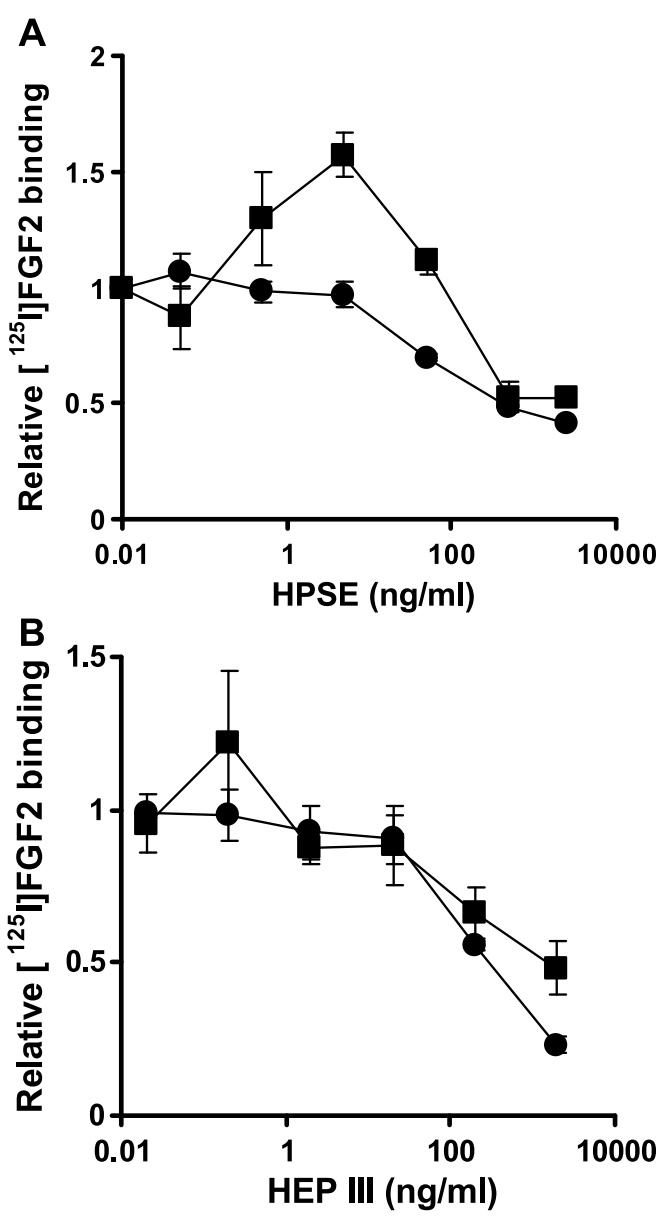

Figure 2. FGF2 binding of HPSE-treated or Hep III-treated human $70 \mathrm{~W}$ melanoma cells. Cells were incubated for 16 hours with indicated concentrations of HPSE (A) or Hep III (B), washed to remove free HS, and incubated for 3 hours with [125I]FGF2. Bound [ ${ }^{125}$ I]FGF2 was separately released from

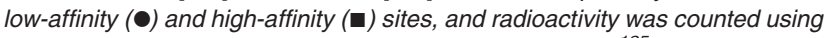
an LKB gamma counter. Binding is reported as the mean $\left[^{125}\right.$ I]FGF2 bound to experimental conditions relative to the mean $\left[^{125}\right.$ I]FGF2 bound to untreated cells from triplicate determinations ( \pm standard deviations).

differing from HPSE and known to inhibit FGF2 binding on other cell types [19]. Low-affinity FGF2 binding to Hep IIIexposed $70 \mathrm{~W}$ cells was maximally inhibited $(77 \%$ inhibition; $P<.005$ ) at $2.5 \mu \mathrm{g} / \mathrm{ml}$ enzymatic concentrations (Figure $2 B$ ). Likewise, Hep III degradation inhibited high-affinity FGF2 binding with maximal inhibition at $2.5 \mu \mathrm{g} / \mathrm{ml}$ Hep III (52\% inhibition; $P<$.005). However, unlike HPSE, Hep III treatment did not significantly enhance FGF2 binding to high-affinity sites (Figure 2B).

\section{HPSE Regulates FGF2 Signal Transduction by Degrading Cell Surface HS}

To determine whether FGF2 signal transduction depends on HPSE treatment of cell surface HSPG, we assessed FGF2-stimulated phosphorylation of molecular components known to be activated during FGF2 signaling. FAK and ERK are phosphorylated by different mechanisms on FGF2 stimulation $[18,21,34]$. 70W cells were exposed to FGF2 following cellular treatment with increasing HPSE concentrations. Untreated cells did not phosphorylate ERK in response to
FGF2 (Figure 3). However, ERK phosphorylation was increased in FGF2-stimulated cells following $0.5 \mathrm{ng} / \mathrm{ml}$ HPSE treatment. Exposure of cells to $5 \mathrm{ng} / \mathrm{ml} \mathrm{HPSE}$ further enhanced FGF2-mediated ERK phosphorylation (Figure 3). Higher HPSE concentrations (5000 ng/ml) eliminated FGF2 stimulation of ERK phosphorylation (Figure 3). The higher HPSE concentration (5000 ng/ml) was used because $500 \mathrm{ng} / \mathrm{ml}$ HPSE reduced FGF2-stimulated ERK phosphorylation but did not abolish FGF2 response (data not shown). Furthermore, FGF2-stimulated FAK phosphorylation occurred only in 70W cells after HPSE treatment (Figure 3). Although FGF2 did not affect FAK phosphorylation in untreated cells, FGF2 stimulated FAK phosphorylation in cells treated with 0.5 to $5 \mathrm{ng} / \mathrm{ml}$ HPSE (Figure 3). As with ERK, HS degradation with $5000 \mathrm{ng} / \mathrm{ml}$ HPSE did not support FGF2-stimulated FAK phosphorylation. Furthermore, FGF2-mediated ERK and FAK phosphorylation (Figure 3) occurred at HPSE concentrations that increased FGF2 binding (Figure 2B).

\section{HPSE-Degraded HS Modulates FGF2 Binding}

Sulfation patterns of HS are cell type-specific, and these patterns have been shown to influence both HPSE activity and FGF2 binding [20]. To define HPSE enzymatic cleavage of HS and heparin used for FGF2 binding and signaling, we first analyzed HS and heparin fragments produced following HPSE treatment. Heparin or HS were incubated with HPSE for 16 hours, and initial assessment of degradation was determined by gel electrophoresis. Because HS were a heterogeneous mixture, they migrate as a broad band during gel electrophoresis (Figure 4A). HPSE-mediated HS degradation resulted in a migration shift, indicating a reduction in HS fragment size (Figure 4A). This shift was small as expected because HPSE does not extensively cleave HS. As control, HS were treated with Hep III, which results in much smaller fragments as indicated by their increased mobility. As expected, HPSE and Hep III degradation of heparin resulted in a shift in migration smaller than the one observed for $\mathrm{HS}$ (Figure 4, $A$ and $B$ ). The leading edge of $\mathrm{HS}$ and heparin profiles was determined after gel densitometric analysis

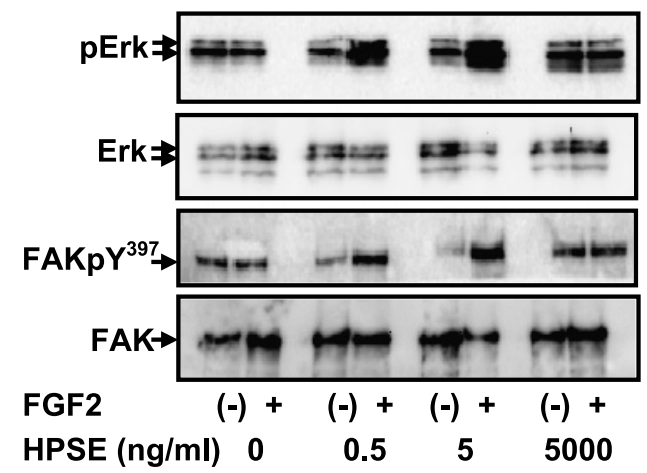

Figure 3. FGF2 signaling in HPSE-treated human 70W melanoma cells. Cells treated with 0 to $5000 \mathrm{ng} / \mathrm{ml}$ HPSE for 16 hours were washed, stimulated for 10 minutes with FGF2 (10 ng/ml), and lysed. Total cell lysates were then analyzed by Western blot analysis for total and phosphorylated ERK and FAK proteins (see Materials and Methods section for details). Results are representative of three independent experiments. 

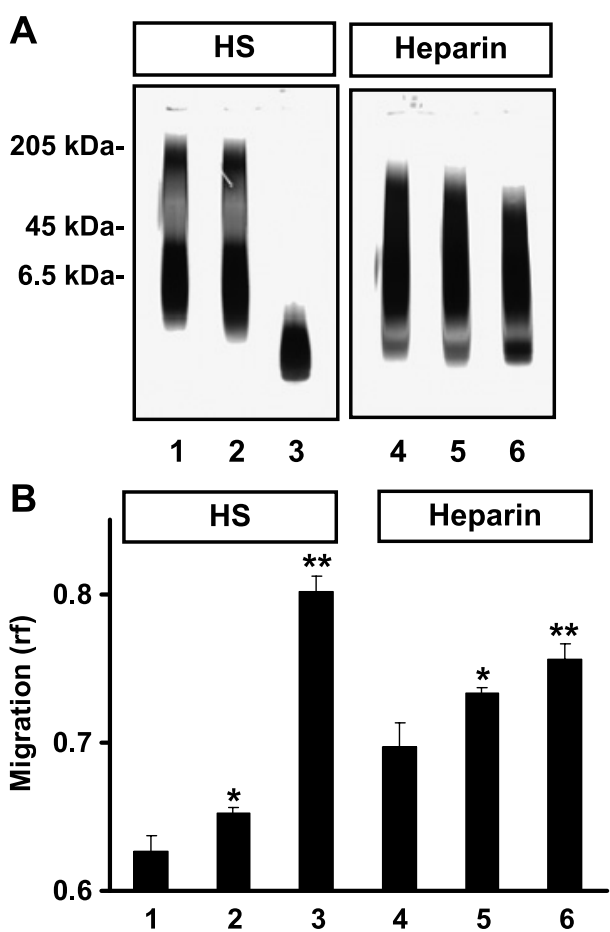

Figure 4. HPSE degrades HS and heparin. To assess HPSE-produced fragments, HS (lanes 1-3) or heparin (lanes 4-6) was incubated for 16 hours at $37^{\circ} \mathrm{C}$ with either buffer alone (lanes 1 and 4), $10 \mu \mathrm{g} / \mathrm{ml} \mathrm{HPSE}$ (lanes 2 and 5), or $100 \mu \mathrm{g} / \mathrm{ml}$ Hep III (lanes 3 and 6). HS and heparin were then separated on a $4 \%$ to $20 \%$ TBE gel, and bands were visualized using Alcian blue dye followed by silver staining (A). Densitometric analysis of the above gel electrophoresis used a Versadoc imaging system (B). Migration is reported as the relative front ( $r f)$ of the leading edge of profiles. Means and standard deviations were determined from triplicate HS profiles. Significant differences were assessed by Student's t test $\left({ }^{*} P<.03\right.$, $\left.{ }^{\star *} P<.005\right)$.

(Figure 4B) and demonstrated consistent shifts toward lowermolecular-weight HS with HPSE treatment compared to non-HPSE-degraded controls $(P<.03)$. To further estimate reaction completion, a time course of HPSE degradation of high-molecular-weight HS was analyzed by HPLC. HS was fluorescently labeled with FITC, and then column chromatography was used to isolate the high-molecular-weight fraction. This was subsequently degraded with HPSE for varying times, and the extent of degradation was assessed using HPLC. A 4-hour HPSE treatment degraded $64 \%$ of initial HS (Table 1), as demonstrated by the profile shift to the right when compared to the non-HPSE-treated HS profile. However, retention time did not show a large shift, indicating that degradation at 4 hours was not complete (Table 1). Conversely, at 16-hour HPSE incubation, both profiles (84\% degraded HS) and retention time shifts of FITC HS were maximal, indicating reaction completion (Table 1).

We then assessed FGF2 binding in the presence of heparin or bovine kidney HS degraded with or without HPSE. Figure 5 shows that both HPSE-degraded HS fragments from heparin (Figure 5, $A$ and $B$ ) and bovine kidney HS (Figure 5, $C$ and $D$ ) inhibited FGF2 low-affinity binding to $70 \mathrm{~W}$ melanoma cells at high (> $10 \mathrm{ng} / \mathrm{ml}$ ) concentrations. Inhibition of lowaffinity binding was similar with HPSE-degraded or intact (nondegraded) heparin (Figure $5 A$ ) and HS (Figure $5 C$ ), although HPSE-degraded heparin was slightly more effective at inhibiting low-affinity binding at low concentrations than intact heparin or HS preparations. Similarly, both HS and heparin inhibited high-affinity FGF2 binding at high concentrations. HPSE degradation of HS or heparin was not required for this binding inhibition. This binding was enhanced by the addition of low concentrations of HPSE-degraded HS or heparin compared to control heparin (Figure $5 B$ ) or HS (Figure 5D). Therefore, HPSE altered HS and heparin; thus, there was an increased high-affinity FGF2 binding at HS concentrations that did not affect low-affinity binding.

HPSE-Degraded HS Modulates FGF2 Signal Transduction

Because HS length and sulfation patterns contributing to FGF2 signal transduction can differ from those required for binding, we examined the ability of HPSE-degraded HS to facilitate FGF2-stimulated ERK and FAK phosphorylation. As observed above, FGF2 failed to stimulate ERK phosphorylation in untreated $70 \mathrm{~W}$ cells (Figure $6, A$ and $B$ ); however, incubation of cells with HPSE-degraded HS recovered FGF2-stimulated ERK phosphorylation (Figure 6A). Likewise, control HS enhanced FGF2-stimulated ERK phosphorylation at all considered concentrations $(1-1000 \mathrm{ng} / \mathrm{ml}$; Figure 6B). FGF2-stimulated ERK phosphorylation was robust by several criteria. First, treatment of cells with $1000 \mathrm{ng} / \mathrm{ml}$ HPSE-degraded HS (Figure 6A) effectively promoted FGF2stimulated ERK phosphorylation despite the inhibition of FGF2 binding (Figure 5, $C$ and $D$ ). This is not completely unexpected as FGF2 activity has been previously found to be more difficult to inhibit than FGF2 binding $[35,36]$. Second, control HS promoted FGF2-stimulated ERK phosphorylation (Figure 6B), although it did not augment FGF2 binding (Figure 5C). Finally, FAK was not phosphorylated in response to FGF2 in control 70W cells (Figure $6, A$ and $B$ ) as was also observed in the HPSE degradation curve (Figure 3). The addition of intact or HPSE-degraded HS did not recover FGF2-stimulated FAK phosphorylation (Figure 6, $A$ and $B$ ), unlike the one detected in response to FGF2 in HPSEexposed cells (Figure 3 ).

\section{HPSE and HPSE-Degraded HS Modulate FGF2-Induced Angiogenesis}

To determine whether degradation of cell surface HS modifies tumor-induced angiogenesis, 70W cells were exposed to increasing HPSE concentrations and injected subcutaneously into athymic nude mice with FGF2 and HPSE. Tumors were excised after 10 days and examined for blood

Table 1. HPLC Analysis of HS Digested by HPSE.

\begin{tabular}{llc}
\hline HS Digestion Time (hr) & Retention Time $(\mathrm{min})$ & \% Digested HS* \\
\hline 0 & 13.5 & 0 \\
4 & 13.9 & 64 \\
8 & 16.2 & 78 \\
16 & 19.1 & 84 \\
24 & 19.2 & 88 \\
\hline
\end{tabular}

*The percentage of digested HS is the amount of HS HPLC profiles shifted out of nontreated control profiles divided by the total HS present. 
vessel formation. FGF2 enhanced melanoma blood vessel formation by 2.3- to 3.6-fold (Figure 7). Treatment of melanoma cells with $10 \mathrm{ng} / \mathrm{ml}$ HPSE enhanced FGF2-induced angiogenesis compared to FGF2 with no HPSE $(P<.05$; Figure 7). Higher HPSE concentrations (1000 ng/ml) did not increase FGF2-induced angiogenesis above controls (FGF2, no HPSE). Treatment of FGF2-stimulated 70W cells with $10 \mathrm{ng} / \mathrm{ml}$ HPSE resulted in augmented angiogenesis compared to either no HPSE $(P<.05)$ or cells treated with $1000 \mathrm{ng} / \mathrm{ml}$ HPSE $(P<.005)$.

To define whether HPSE-degraded HS enhanced FGF2-induced angiogenesis, melanoma cells treated with HPSE-degraded HS, or mock-degraded intact HS, were subcutaneously injected into athymic nude mice in the presence/absence of FGF2. FGF2 did not stimulate additional angiogenesis above basal levels in melanoma tumors injected without HS (Figure 8). This may be due to higher basal levels of angiogenesis in these experiments compared to ones without enzyme pretreatment (Figure 7). This is possibly due to the conditions used for enzyme pretreatment. Melanoma tumors treated with HPSE-degraded HS and FGF2 had a significant increase in blood vessel density compared to either no FGF2 $(P<.005)$ or FGF2 but no HS treatments $(P<.03)$. Furthermore, the addition of intact HS with FGF2 did not result in augmented angiogenesis above basal levels.

\section{Discussion}

We report first-time evidence that HPSE alters metastatic melanoma cell responsiveness to FGF2, including FGF2 binding, signaling, and FGF2-induced angiogenesis. This provides a mechanism by which metastatic melanoma cells can become more responsive to FGF2, a growth factor that is important in melanoma progression. We have shown that HPSE degradation of cell surface HS can both augment and inhibit FGF2 activity, depending on the HPSE concentrations used to remodel cell surface HS. We have demonstrated a specificity of HPSE-modulated FGF2 increase in binding and signaling because, when we exposed cells to Hep III, a bacterial endoglycosidase, we observed a dose-dependent inhibition of FGF binding and signaling; however, there was no detectable increase. We also found that HPSE degradation of soluble heparin or HS produces fragments that either potentiate or inhibit melanoma cell FGF2 binding and signaling in an HS concentration-dependent manner. In addition, our results demonstrate that FGF2-mediated signaling pathways are differentially affected depending on whether cleaved HS are: 1) attached to cell surface HSPG or 2) in soluble form. Although we found that HPSE is able to stimulate FGF2-mediated angiogenesis, high levels of HPSE, which cause extensive HS degradation, are unable to support FGF2-mediated angiogenesis. Finally, we found that HPSE-produced HS fragments are able to promote FGF2-
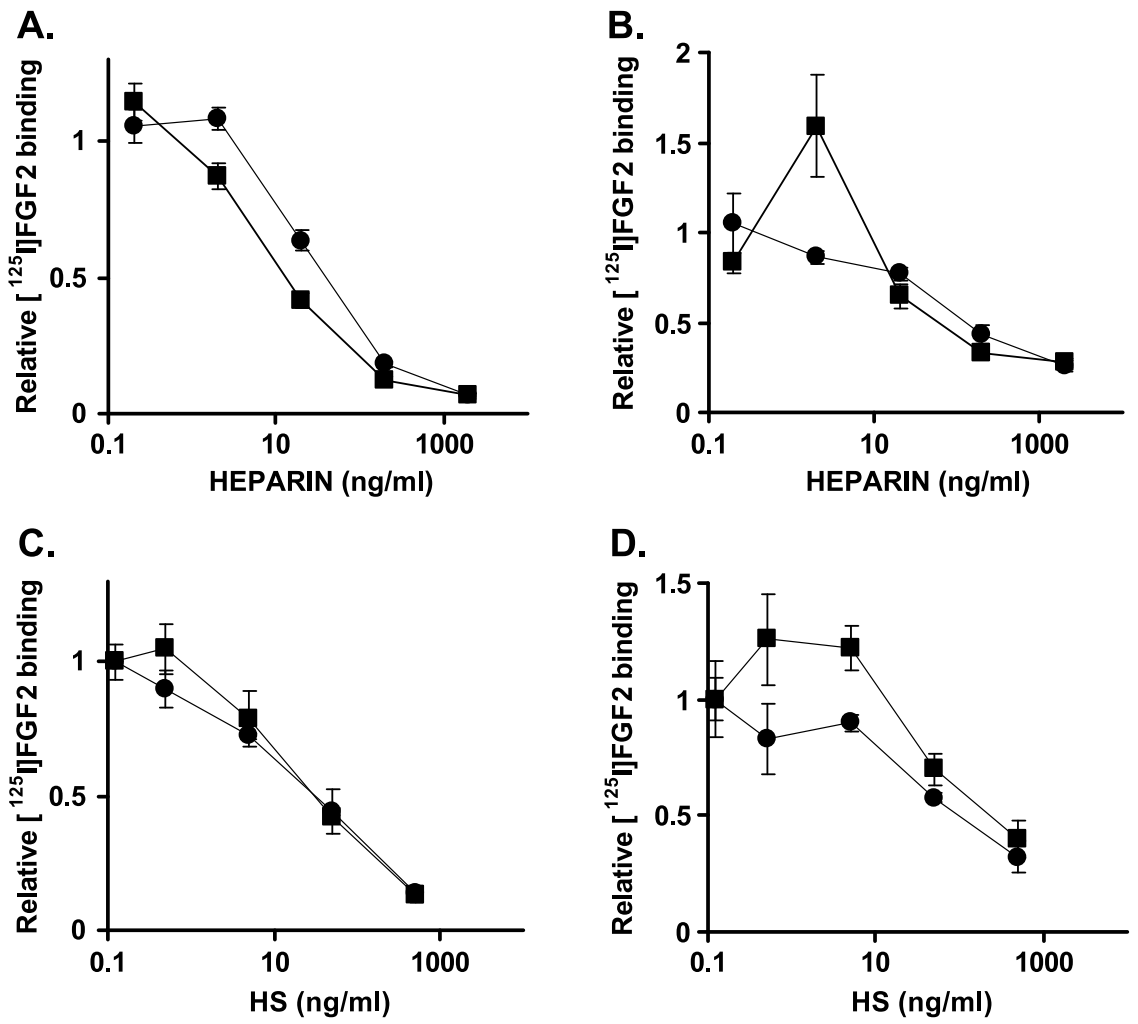

Figure 5. HPSE degradation of heparin or HS produces fragments that modulate FGF2 binding. Human 70W melanoma cells were incubated with [125I]FGF2 and

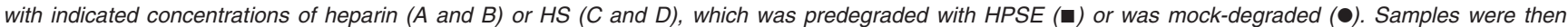
assayed for [ ${ }^{125}$ I]FGF2 binding to low-affinity $(A$ and $C)$ or high-affinity ( $B$ and $\left.D\right)$ sites. Binding is reported as the mean [125I]FGF2 bound with experimental conditions relative to the mean ${ }^{125}$ I]FGF2 bound to untreated control cells from triplicate determinations ( \pm standard deviations). 

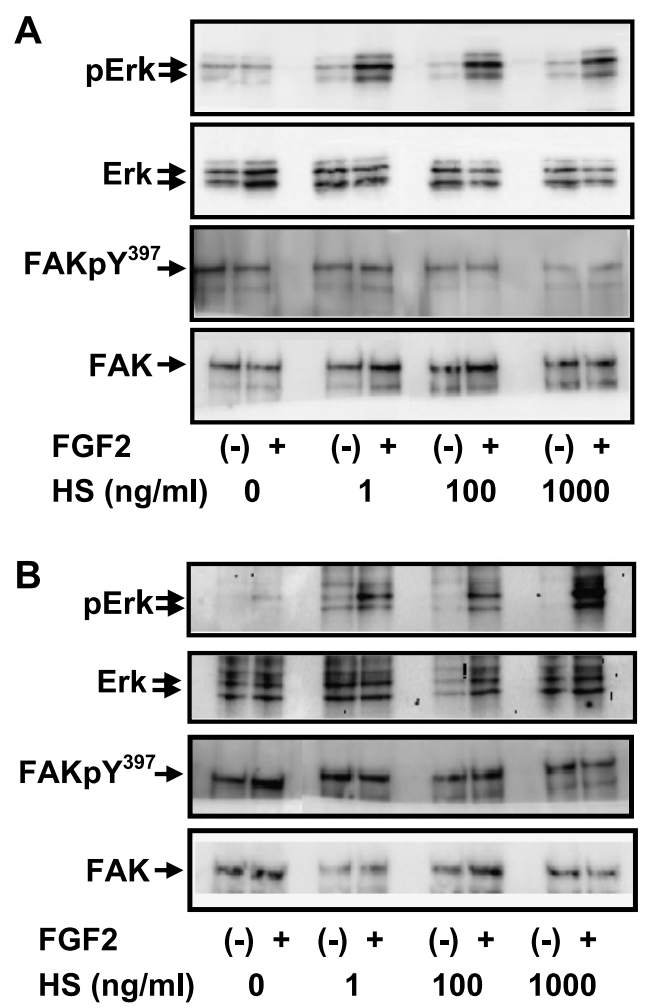

Figure 6. HPSE degradation of heparin or HS produces fragments that modulate FGF2-stimulated Erk but not FAK phosphorylation. Cells were incubated for 10 minutes with FGF2 $(10 \mathrm{ng} / \mathrm{ml})$ in the presence of indicated concentrations of HS predegraded with HPSE (A) or mock-degraded (B). Cells were lysed and total cell extracts were analyzed by Western blot analysis for total/phosphorylated forms of ERK or FAK, respectively (see Materials and Methods section for details). Results are representative of three independent experiments.

stimulated tumor angiogenesis in the complete absence of HPSE. Altogether, these results provide a relevant mechanism to elucidate how HPSE regulates tumor angiogenesis.

The high-affinity ternary complex includes FGF2 and HS as well as FGFR, which initiates signal transduction through its tyrosine kinase domain [37]. Structural analysis indicates that HS interacts with both FGF and FGFR in forming the high-affinity ternary complex $[38,39]$. However, HS requirements for binding and signaling are not equivalent [40]. Native HS on untreated $70 \mathrm{~W}$ cells does not support FGF2stimulated signaling, although it sustains binding. However, HPSE can modify cellular HS to support FGF2-stimulated signaling, potentially through modifying HS structures to alter interactions with either FGF2 or FGFR, or both. HS interactions can promote FGF2-FGFR dimerization initiating transphosphorylation of the receptor and signaling, as correct stoichiometry is required for FGF2 signaling [37,41]. Alternatively, HS may affect additional signal pathways required for efficient propagation of FGF2 signaling $[6,42]$.

High-affinity FGF2 binding and signaling require $\mathrm{HS}$ sequence-specific interactions. Depending on the extent of HS degradation, HS sequences, which bind to either FGF2 or FGFR, could be removed or cryptic sites could be revealed $[24,43]$. HS are highly heterogeneous oligomers due to exten- sive postsynthesis modification of the basic GlcUA $\beta_{1,4} \mathrm{GlcNAc}$ unit. HPSE cleaves HS within a specified minimum sequence (-GlcNAc(6S)-GlcUA-GlcN(NS)- $)_{3}$ but also requires additional sulfation in the surrounding sequence [44]. Sites for HPSE cleavage occur infrequently in HS from multiple sources, producing long fragments capable of promoting FGF2 activity. There may also be additional sites of cleavage [45] that are suppressed in highly sulfated regions [44]. The HPSE cleavage sequence in HS does not overlap with the FGF2 HS binding site, which requires 2- $O$ sulfation in the sequence $\mathrm{HexA}\left(2 \mathrm{SO}_{4}\right)-\mathrm{GlcNSO}_{3}$ for binding [46,47]. Highly sulfated regions are more effective at FGF2 binding as multiple $2-O$ sulfation increases binding $[48,49]$. In addition, HS binding to the FGFR requires $6-O$ sulfation, which is critical for strengthening FGF-FGFR binding and promoting receptor dimerization [40]. Conversely, Hep III produces HS fragments that are rich in $\operatorname{IdoUA}(2 S) \alpha_{1,4} \mathrm{GlcNSO}_{3}( \pm 6 S)$ disaccharides [50], and HS degradation is significantly more extensive than with HPSE, resulting in the production of shorter HS fragments. Although highly sulfated HS with as few as four disaccharides units can bind to FGF2, longer oligomers are required for effective formation of the FGF2-FGFR stoichiometry required for subsequent signaling [51].

HPSE cleavage of HS can potentially change core protein membrane localization, consequently altering their availability to interact with FGFR or other signaling molecules. This has been demonstrated with the HSPG syndecan-1 [52] and glypican [53], whose localization in the plasma membrane is affected by removing HS or by inhibiting HS interactions.

HPSE can release soluble HS from both cell surface and ECM HSPG and therefore alter the composition of soluble HS available to the cell. Previously, it has been shown that HPSE degradation of ECM releases HS with FGF2 in a bioactive form [23]. It has also been demonstrated that HS produced by bacterial heparitinases promoted tumorigenesis, depending on HS sequence specificity of the enzyme. We now demonstrate that HPSE, a unique mammalian HS degradative enzyme that is present during tumor progression and in normal physiological events, produces $\mathrm{HS}$, which potentiate or inhibit FGF2 binding and signaling according to HS concentration and the signaling intermediate. In addition, these $\mathrm{HS}$ also promote tumor angiogenesis. Potentiation of FGF2 binding is more pronounced with HPSE-degraded heparin, possibly because the increased sulfation on heparin presents more FGF2 or FGFR binding sites. Enhanced binding and ERK signaling could result from soluble HS, which are more efficient than endogenous HS in the formation of the ternary FGFR complex. It is unexpected that shorter HS formed by HPSE degradation enhance ternary complex formation, whereas longer intact HS do not. Again, this suggests that HPSE cleavage may reveal cryptic binding sites or changes in HS concentration and length that influence the stoichiometry of the ternary complex.

In the melanoma cells used in this study, FGF2-stimulated FAK phosphorylation required HPSE remodeling of resident HSPG, and soluble HS did not recover FAK phosphorylation (Figures 2 and 4). FGF2 signaling involves cross-talk or stimulation with other signal transduction pathways [54]. 
For example, FGF2 can increase FAK phosphorylation initiated through integrins in an HS-dependent manner [21]. HPSE can activate integrins, which are known to phosphorylate FAK [29]. Therefore, in our cells, FAK may be sufficiently downstream of FGF2 that it requires activation of additional pathways for phosphorylation [9]. HSPG roles are of further interest because reducing the number of $\mathrm{HS}$ attached to a single core protein can inhibit the ability of HSPG to promote cell adhesion and invasion [55]. This would subsequently inhibit signaling dependent on these adhesive interactions.

We also found a modulation of tumor angiogenesis by HPSE and HPSE-degraded HS. Angiogenesis is dependent on multiple components that can be affected by HPSE. HS in the ECM provide binding sites for angiogenic factors such as FGF2 and vascular endothelial growth factor. Cell surface HSPG acts as growth factor and adhesion receptors on tumor cells and vascular endothelial cells. Modifying the HS may affect tumorigenicity by modifying the responsiveness of multiple receptors to the extracellular environment. In addition, HPSE releases HS from the ECM, which can alter binding and signaling initiated through endothelial or tumor $\mathrm{HS}$ binding cell surface receptors.

Finally, recent evidence suggests that, although HPSE upregulation in glioma cells results in augmented tumor aggressiveness, further elevation of HPSE inhibits tumorigenicity [29]. Our work not only extends this notion to metastatic melanoma, suggesting that HPSE modulates tumor responsiveness in multiple systems, but also demonstrates that these changes can be affected by HPSE-mediated HS remodeling of the tumor cell surface and the ECM. Extensive degradation of cell surface HS can interfere with growth factor binding and internalization [2,3]. However, a modest degradation of cell surface HS could modify the structure of HS, resulting in either decreased or increased interactions depending on the growth factor. Furthermore, HPSE degradation of HS could change the availability of FGF2 in the tumor microenvironment by releasing FGF2 from the matrix and the cell surface. In addition to modifying FGF2 action, HPSE could alter signaling initiated by multiple heparin binding growth factors, fine-tuning cellular response to changes in its environment. Besides FGF2, melanoma cells respond to heparin binding growth factors, such as pleiotrophin and vascular endothelial growth factor, whose binding and signaling are also influenced by available HS [56,57]. This in turn can allow differing modifications of various biologic responses, such as angiogenesis or metastasis, depending on growth factors' availability and the amount of HPSE present. It will be of interest to determine HPSE effects on the
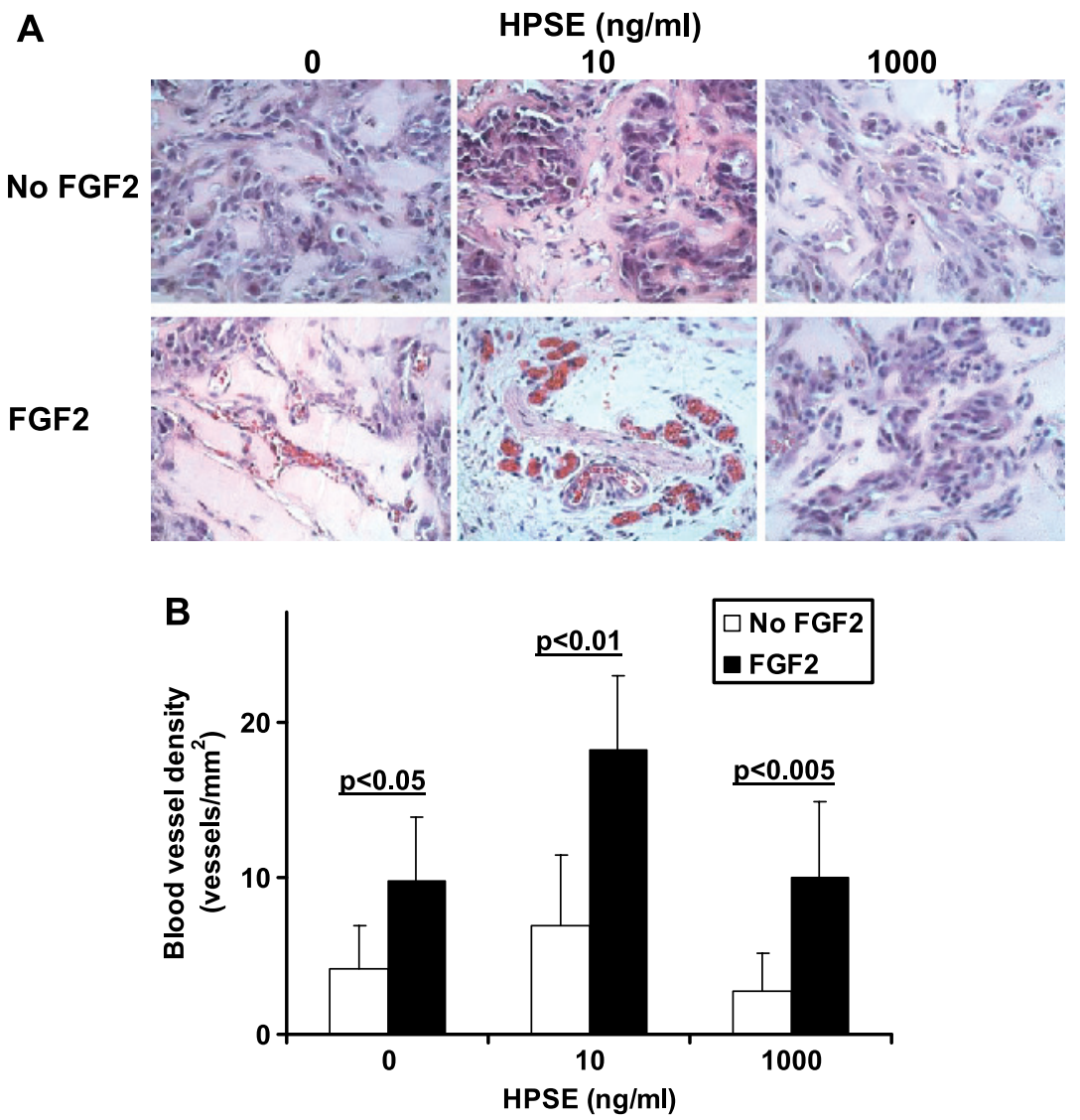

Figure 7. HPSE degradation of melanoma cell surface HS modulates FGF2-induced tumor angiogenesis. $70 \mathrm{~W}$ cells were incubated for 16 hours with indicated HPSE concentrations. Cells were then released, resuspended with Matrigel in the presence or absence of FGF2, and injected subcutaneously into athymic nude mice $(n=10)$. Tumors were allowed to grow for 10 days, excised, and formalin-fixed, and sections were stained with H\&E (A). Blood vessels were quantified using nine fields each of three independent sections per tumor (B). Original magnification, $\times 40$. Bar, $25 \mu \mathrm{m}$. Errors are reported at $90 \%$ confidence intervals. 


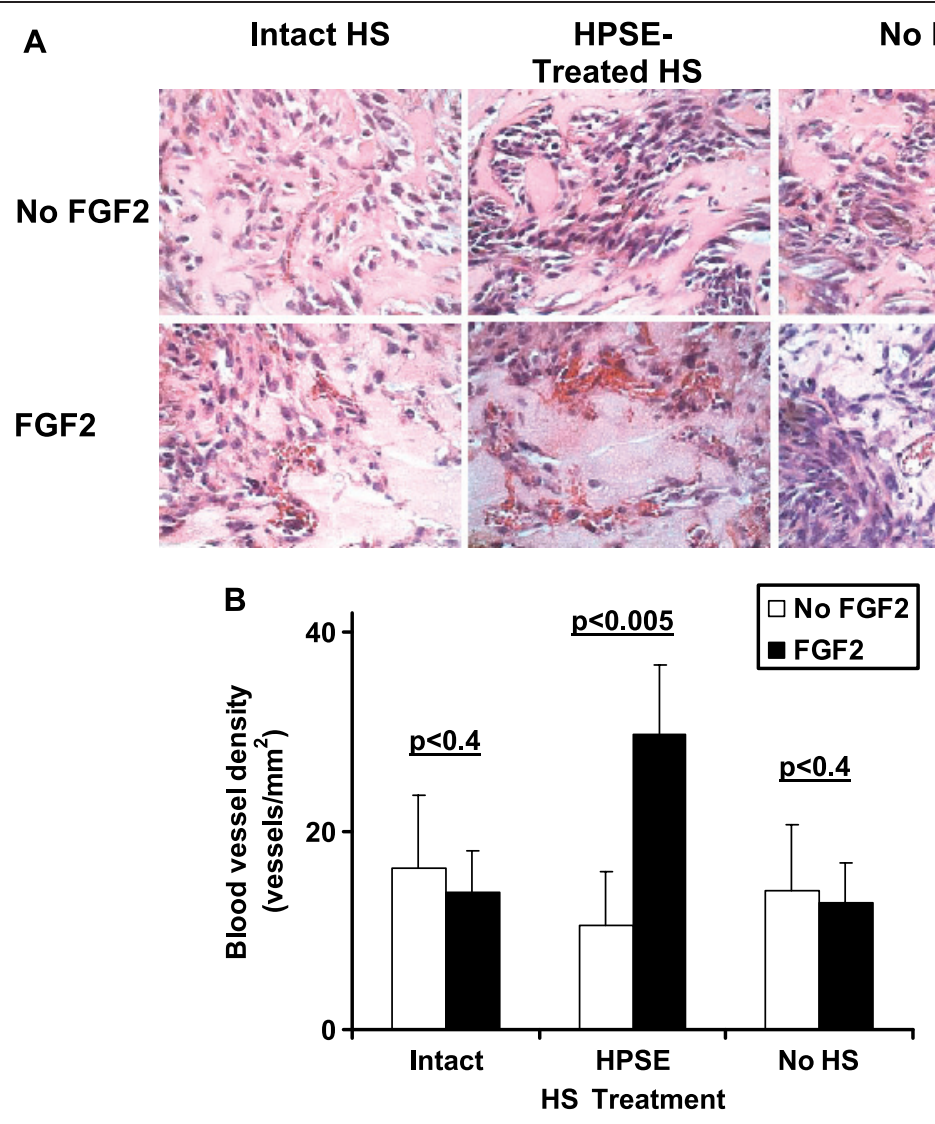

Figure 8. HPSE-degraded HS modulate FGF2 stimulation of melanoma tumor angiogenesis. Cells were released, resuspended with Matrigel in the presence or absence of FGF2 and indicated HS, and injected into athymic nude mice subcutaneously $(n=8)$. Tumors were allowed to grow for 10 days, excised, and formalinfixed, and sections were stained with H\&E (A). Blood vessels were quantified using nine fields each of three independent sections per tumor (B). Original magnification, $\times 40$. Bar, $25 \mu \mathrm{m}$. Errors are reported at $90 \%$ confidence intervals.

binding and signaling of these and other heparin binding growth factors and their related receptors, thus amplifying our knowledge of HPSE-based mechanisms of action.

\section{Acknowledgements}

We thank Edward McKenzie (School of Biological Sciences, University of Manchester, Manchester, England, UK) for providing baculovirus transfer vectors for human recombinant HPSE production. We also thank Marian Waguespack and Steven A. Barker for their expert assistance with HPLC, and Gregory McCormick for technical assistance with immunofluorescence experiments.

\section{References}

[1] Fjeldstad K and Kolset SO (2005). Decreasing the metastatic potential in cancers - targeting the heparan sulfate proteoglycans. Curr Drug Targets 6, 665-682.

[2] Sanderson RD (2001). Heparan sulfate proteoglycans in invasion and metastasis. Semin Cell Dev Biol 12, 89-98.

[3] Iozzo RV (2001). Heparan sulfate proteoglycans: intricate molecules with intriguing functions. J Clin Invest 108, 165-167.

[4] Powell AK, Yates EA, Fernig DG, and Turnbull JE (2004). Interactions of heparin/heparan sulfate with proteins: appraisal of structural factors and experimental approaches. Glycobiology 14, 17R-30R.

[5] Herlyn M (2005). Metastatic melanoma cells. Introduction. Cancer Metastasis Rev 24, 193-194.
[6] Rapraeger AC (1995). In the clutches of proteoglycans: how does heparan sulfate regulate FGF binding? Chem Biol 2, 645-649.

[7] Ornitz DM, Yayon A, Flanagan JG, Svahn CM, Levi E, and Leder P (1992). Heparin is required for cell-free binding of basic fibroblast growth factor to a soluble receptor and for mitogenesis in whole cells. Mol Cell Biol 12, 240-247.

[8] Rapraeger AC, Krufka A, and Olwin BB (1991). Requirement of heparan sulfate for bFGF-mediated fibroblast growth and myoblast differentiation. Science 252, 1705-1708.

[9] Boilly B, Vercoutter-Edouart AS, Hondermarck H, Nurcombe V, and LeBourhis $X$ (2000). FGF signals for cell proliferation and migration through different pathways. Cytokine Growth Factor Rev 11, 295-302.

[10] Hunger-Glaser I, Fan RS, Perez-Salazar E, and Rozengurt E (2004). PDGF and FGF induce focal adhesion kinase (FAK) phosphorylation at Ser-910: dissociation from Tyr-397 phosphorylation and requirement for ERK activation. J Cell Physiol 200, 213-222.

[11] Easty DJ and Bennett DC (2000). Protein tyrosine kinases in malignant melanoma. Melanoma Res 10, 401-411.

[12] Smalley KS (2003). A pivotal role for ERK in the oncogenic behaviour of malignant melanoma? Int J Cancer 104, 527-532.

[13] Wozniak MA, Modzelewska K, Kwong L, and Keely PJ (2004). Focal adhesion regulation of cell behavior. Biochim Biophys Acta 1692, 103-119.

[14] Sieg DJ, Hauck CR, Ilic D, Klingbeil CK, Schaefer E, Damsky CH, and Schlaepfer DD (2000). FAK integrates growth-factor and integrin signals to promote cell migration. Nat Cell Biol 2, 249-256.

[15] Abdel-Ghany M, Cheng HC, Elble RC, and Pauli BU (2002). Focal adhesion kinase activated by beta(4) integrin ligation to mCLCA1 mediates early metastatic growth. J Biol Chem 277, 34391-34400.

[16] Schlaepfer DD and Mitra SK (2004). Multiple connections link FAK to cell motility and invasion. Curr Opin Genet Dev 14, 92-101.

[17] Lin TH, Aplin AE, Shen Y, Chen Q, Schaller M, Romer L, Aukhil I, and Juliano RL (1997). Integrin-mediated activation of MAP kinase is independent of FAK: evidence for dual integrin signaling pathways in fibroblasts. J Cell Biol 136, 1385-1395.

[18] Yang J, Price MA, Neudauer CL, Wilson C, Ferrone S, Xia H, lida J, 
Simpson MA, and McCarthy JB (2004). Melanoma chondroitin sulfate proteoglycan enhances FAK and ERK activation by distinct mechanisms. J Cell Biol 165, 881-891.

[19] Rapraeger AC (2002). Heparan sulfate-growth factor interactions. Methods Cell Biol 69, 83-109.

[20] Berry D, Shriver Z, Natke B, Kwan CP, Venkataraman G, and Sasisekharan R (2003). Heparan sulphate glycosaminoglycans derived from endothelial cells and smooth muscle cells differentially modulate fibroblast growth factor-2 biological activity through fibroblast growth factor receptor-1. Biochem J 373, 241-249.

[21] Nurcombe V, Smart CE, Chipperfield H, Cool SM, Boilly B, and Hondermarck $H$ (2000). The proliferative and migratory activities of breast cancer cells can be differentially regulated by heparan sulfates. J Biol Chem 275, 30009-30018.

[22] Rahmoune H, Chen HL, Gallagher JT, Rudland PS, and Fernig DG (1998). Interaction of heparan sulfate from mammary cells with acidic fibroblast growth factor (FGF) and basic FGF. Regulation of the activity of basic FGF by high and low affinity binding sites in heparan sulfate. $J$ Biol Chem 273, 7303-7310.

[23] Vlodavsky I and Friedmann Y (2001). Molecular properties and involvement of heparanase in cancer metastasis and angiogenesis. $J$ Clin Invest 108, 341-347.

[24] Kato M, Wang H, Kainulainen V, Fitzgerald ML, Ledbetter S, Ornitz DM, and Bernfield M (1998). Physiological degradation converts the soluble syndecan-1 ectodomain from an inhibitor to a potent activator of FGF-2. Nat Med 4, 691-697.

[25] Murry BP, Greiter-Wilke A, Paulsen DP, Hiatt KM, Beltrami CA, and Marchetti D (2005). Selective heparanase localization in malignant melanoma. Int J Oncol 26, 345-352.

[26] Goldshmidt O, Zcharia E, Abramovitch R, Metzger S, Aingorn H, Friedmann Y, Schirrmacher V, Mitrani E, and Vlodavsky I (2002). Cell surface expression and secretion of heparanase markedly promote tumor angiogenesis and metastasis. Proc Natl Acad Sci USA 99, $10031-10036$

[27] Roy M, Reiland J, Murry BP, Chouljenko V, Kousoulas KG, and Marchetti D (2005). Antisense-mediated suppression of heparanase gene inhibits melanoma cell invasion. Neoplasia 7, 253-262.

[28] Edovitsky E, Elkin M, Zcharia E, Peretz T, and Vlodavsky I (2004). Heparanase gene silencing, tumor invasiveness, angiogenesis, and metastasis. J Natl Cancer Inst 96, 1219-1230.

[29] Zetser A, Bashenko Y, Miao HQ, Vlodavsky I, and Ilan N (2003). Heparanase affects adhesive and tumorigenic potential of human glioma cells. Cancer Res 63, 7733-7741.

[30] Reiland J, Sanderson RD, Waguespack M, Barker SA, Long R, Carson DD, and Marchetti D (2004). Heparanase degrades syndecan-1 and perlecan heparan sulfate: functional implications for tumor cell invasion. $J$ Biol Chem 279, 8047-8055.

[31] McKenzie E, Young K, Hircock M, Bennett J, Bhaman M, Felix R, Turne P, Stamps A, McMillan D, Saville G, et al. (2003). Biochemical characterization of the active heterodimer form of human heparanase (Hpa1) protein expressed in insect cells. Biochem $J \mathbf{3 7 3}, 423-435$.

[32] Pervin A, Gallo C, Jandik KA, Han XJ, and Linhardt RJ (1995). Preparation and structural characterization of large heparin-derived oligosaccharides. Glycobiology 5, 83-95.

[33] Olwin BB and Rapraeger A (1992). Repression of myogenic differentiation by aFGF, bFGF, and K-FGF is dependent on cellular heparan sulfate. J Cell Biol 118, 631-639.

[34] Holmqvist K, Cross M, Riley D, and Welsh M (2003). The Shb adaptor protein causes Src-dependent cell spreading and activation of focal adhesion kinase in murine brain endothelial cells. Cell Signal 15, $171-179$.

[35] Natke B, Venkataraman G, Nugent MA, and Sasisekharan R (1999). Heparinase treatment of bovine smooth muscle cells inhibits fibroblast growth factor-2 binding to fibroblast growth factor receptor but not FGF2 mediated cellular proliferation. Angiogenesis 3, 249-257.

[36] Krufka A, Guimond S, and Rapraeger AC (1996). Two hierarchies of FGF-2 signaling in heparin: mitogenic stimulation and high-affinity binding/receptor transphosphorylation. Biochemistry 35, 11131-11141.

[37] Powers CJ, McLeskey SW, and Wellstein A (2000). Fibroblast growth factors, their receptors and signaling. Endocr-Relat Cancer 7, 165-197.

[38] Ibrahimi OA, Yeh BK, Eliseenkova AV, Zhang F, Olsen SK, Igarashi M, Aaronson SA, Linhardt RJ, and Mohammadi M (2005). Analysis of mutations in fibroblast growth factor (FGF) and a pathogenic mutation in FGF receptor (FGFR) provides direct evidence for the symmetric two-end model for FGFR dimerization. Mol Cell Biol 25, 671-684.

[39] Robinson CJ, Harmer NJ, Goodger SJ, Blundell TL, and Gallagher JT (2005). Cooperative dimerization of fibroblast growth factor 1 (FGF1) upon a single heparin saccharide may drive the formation of 2:2:1 FGF1FGFR2c-heparin ternary complexes. J Biol Chem 280, 42274-42282.

[40] Mohammadi M, Olsen SK, and Ibrahimi OA (2005). Structural basis for fibroblast growth factor receptor activation. Cytokine Growth Factor Rev 16, 107-137.

[41] Bellot F, Crumley G, Kaplow JM, Schlessinger J, Jaye M, and Dionne CA (1991). Ligand-induced transphosphorylation between different FGF receptors. EMBO J 10, 2849-2854.

[42] Newman DR, Li CM, Simmons R, Khosla J, and Sannes PL (2004). Heparin affects signaling pathways stimulated by fibroblast growth factor-1 and -2 in type II cells. Am J Physiol Lung Cell Mol Physiol 287, L191-L200.

[43] Liu D, Shriver Z, Venkataraman G, El Shabrawi Y, and Sasisekharan R (2002). Tumor cell surface heparan sulfate as cryptic promoters or inhibitors of tumor growth and metastasis. Proc Natl Acad Sci USA 99, $568-573$.

[44] Okada Y, Yamada S, Toyoshima M, Dong J, Nakajima M, and Sugahara K (2002). Structural recognition by recombinant human heparanase that plays critical roles in tumor metastasis. Hierarchical sulfate groups with different effects and the essential target disulfated trisaccharide sequence. J Biol Chem 277, 42488-42495.

[45] Gong F, Jemth P, Escobar Galvis ML, Vlodavsky I, Horner A, Lindahl U, and Li JP (2003). Processing of macromolecular heparin by heparanase. J Biol Chem 278, 35152-35158.

[46] Salmivirta M, Lidholt K, and Lindahl U (1996). Heparan sulfate: a piece of information. FASEB J 10, 1270-1279.

[47] Ashikari-Hada S, Habuchi H, Kariya Y, Itoh N, Reddi AH, and Kimata K (2004). Characterization of growth factor-binding structures in heparin/ heparan sulfate using an octasaccharide library. J Biol Chem 279, $12346-12354$.

[48] Jemth P, Kreuger J, Kusche-Gullberg M, Sturiale L, Gimenez-Gallego $G$, and Lindahl U (2002). Biosynthetic oligosaccharide libraries for identification of protein-binding heparan sulfate motifs. Exploring the structural diversity by screening for fibroblast growth factor (FGF)1 and FGF2 binding. J Biol Chem 277, 30567-30573.

[49] Kreuger J, Salmivirta M, Sturiale L, Gimenez-Gallego G, and Lindahl U (2001). Sequence analysis of heparan sulfate epitopes with graded affinities for fibroblast growth factors 1 and 2. J Biol Chem 276, 30744-30752.

[50] Pye DA, Vives RR, Turnbull JE, Hyde P, and Gallagher JT (1998). Heparan sulfate oligosaccharides require 6-O-sulfation for promotion of basic fibroblast growth factor mitogenic activity. J Biol Chem 273, 22936-22942.

[51] Delehedde M, Lyon M, Gallagher JT, Rudland PS, and Fernig DG (2002). Fibroblast growth factor-2 binds to small heparin-derived oligosaccharides and stimulates a sustained phosphorylation of p42/44 mitogen-activated protein kinase and proliferation of rat mammary fibroblasts. Biochem J 366, 235-244.

[52] Yang Y, Borset M, Langford JK, and Sanderson RD (2003). Heparan sulfate regulates targeting of syndecan-1 to a functional domain on the cell surface. J Biol Chem 278, 12888-12893.

[53] Mertens G, Van der Schueren B, van den Berghe $H$, and David $G$ (1996). Heparan sulfate expression in polarized epithelial cells: the apical sorting of glypican (GPI-anchored proteoglycan) is inversely related to its heparan sulfate content. J Cell Biol 132, 487-497.

[54] Presta M, Dell'Era P, Mitola S, Moroni E, Ronca R, and Rusnati M (2005). Fibroblast growth factor/fibroblast growth factor receptor system in angiogenesis. Cytokine Growth Factor Rev 16, 159-178.

[55] Langford JK, Stanley MJ, Cao D, and Sanderson RD (1998). Multiple heparan sulfate chains are required for optimal syndecan-1 function. J Biol Chem 273, 29965-29971.

[56] Lazar-Molnar E, Hegyesi H, Toth S, and Falus A (2000). Autocrine and paracrine regulation by cytokines and growth factors in melanoma. Cytokine 12, 547-554.

[57] Wu H, Barusevicius A, Babb J, Klein-Szanto A, Godwin A, Elenitsas R, Gelfand JM, Lessin S, and Seykora JT (2005). Pleiotrophin expression correlates with melanocytic tumor progression and metastatic potential. J Cutan Pathol 32, 125-130. 